\title{
En kvinne i 40-årene med utslett og flekker på munnslimhinne
}

\author{
Kombinasjonen av feber, konjunktivitt og makuløst utslett kan by på \\ diagnostiske utfordringer.
}

\author{
Sveinung Larsen* \\ sveinung.larsen@hotmail.com \\ Indremedisinsk avdeling \\ Sykehuset Innlandet, Elverum \\ Hanne Nøkleby \\ Divisjon for smittevern \\ Nasjonalt folkehelseinstitutt \\ Dag Amundsen** \\ Indremedisinsk avdeling \\ Sykehuset Innlandet, Elverum \\ Nåværende adresser: \\ * Barneavdelingen, Sykehuset Innlandet, \\ Lillehammer \\ ** Indremedisinsk avdeling, Sykehuset Innlandet, \\ Lillehammer
}

Pasienten er en kvinne i slutten av 40-årene som ble innlagt med en seks dagers sykehistorie med sårhet $i$ hals, feber, hoste og tiltakende redusert allmenntilstand. Hun var tidligere kolecystektomert på grunn av hyppige gallesteinsanfall. I tillegg var hun plaget av kroniske nakkesmerter etter en bilulykke og var operert for Mortons metatarsalgi. Tredje dag etter debut av feber fikk hun utslett på haken som etter hvert spredte seg til skuldre, truncus, håndledd og knær. Femte dag etter debut fikk hun røde og smertefulle øyne. Hun hadde målt temperatur hjemme til $39,7^{\circ} \mathrm{C}$ rektalt.

Ved somatisk undersøkelse i mottak hadde hun BT 120/71 mm Hg, regelmessig puls $94 \mathrm{slag} / \mathrm{min}$, temperatur $38,3^{\circ} \mathrm{C}$ med øretermometer. Hun hadde konjunktivitt, hvitt belegg på tungen, forstørrede og injiserte tonsiller uten pusspropper. Lymfeknutene på halsen var litt ømme, og hun hadde et makuløst erytem i ansikt, truncus og ekstremiteter som bleknet ved trykk. Det var normale funn ved auskultasjon av hjerte og lunger. Det var ingen tegn til artritt, hun hadde normalt EKG og urinstiks var negativ. Orienterende blodprøver ved innleggelsen viste normal $\mathrm{Hb}$ og hvite blodceller. Differensialtelling viste at tallet på lymfocytter var lavt, 0,3 $(1,5-4,0)$, men var ellers normal. Hun hadde forhøyet CRP 83 ( 1 1), ALAT $240 \mathrm{U} / \mathrm{l}(10-45)$ og hypokalsemi, med kalsiumnivå på 2,08 mmol/l (2.15-2.51). Andre blodprøver var innenfor referanseområdet.
Pasienten ble innlagt med tentativ diagnose skarlagensfeber. Det ble sikret bakteriologiske prøver fra hals og startet opp antibiotikabehandling med penicillin 2 millioner IE $\times 4$ intravenøst. Forventet total behandlingstid med penicillin ble satt til ti dager. Hun ble lagt på luftsmitterom og isolert til to døgn etter oppstart av antibiotika. Det ble satt opp utvidede kontrollprøver av leverparametere påfølgende dag. Hennes forhøyede leverprøver ble vurdert som et resultat av den antatte systemiske bakterielle infeksjonen.

Kontrollblodprøver påfølgende dag viste ASAT U/l 228 (15-35), ALAT 271 U/l (10-45), laktatdehydrogenase (LD) 531 U/l (105-205), gamma-GT 226 U/l (10-75), INR 1,8 (0,9-1,2) albumin $32 \mathrm{~g} / \mathrm{l}$ (normalt 36-45). CRP var stigende til 89. Serologisk undersøkelse for Epstein-Barr-virus var negativ.

Ved visitt tredje dag ble det registrert at utslettet hadde en sentrifugal utbredelse fra ansiktet og distalt ut mot truncus og ekstremiteter. Det ble også bemerket at hun hadde konjunktivitt. Ved inspeksjon av munnslimhinne ble det funnet små hvite saltkornaktige flekker, og det ble reist spørsmål om dette kunne være såkalte koplikske flekker, som er patognomonisk for meslinger. Muligheten for at hun hadde meslinger, ble diskutert blant kolleger ved legemøtet, men ble holdt for å være lite sannsynlig.

Hun ble samme dag satt på peroral behandling med fenoksymetylpenicillin $660 \mathrm{mg} \times 4$. Ved nærmere samtale kunne pasienten fortelle at hun i sitt arbeid hadde vært i nær kontakt med blant annet flyktninger fra Afghanistan, Iran og Irak. Det ble konferert med infeksjonsmedisiner, som ikke så ytterligere behov for isolering og pasienten ble tatt ut av isolat. Serologi for meslinger ble sikret. Nye blodprøver viste fallende CRP til $22(<1)$, men økende transaminaser. ASAT var nå på 419 U/1 (15-35) og ALAT 482 U/1 (10-45). Øvrige blodprøver var normale. Hun ble overført til gastroenterologisk avdeling på grunn av økende transaminaseverdier.

Ved gastroenterologisk avdeling ble det tatt serologi for hepatitt $A, B$ og $C$. Alle disse var negative. Hivtest var negativ. På grunn av tilfeller av kongenitt leverfibrose og systemisk lupus erythematosus (SLE) i nær familie konfererte man med gastroenterolog på Rikshospitalet og diskuterte muligheten for bakenforliggende leversykdom. Hun hadde hatt et tilfelle tidligere med stigning av transaminaser, men da i forbindelse med kolecystektomi. Det ble på denne bakgrunn tatt serologiske prøver for ANCA, antimitokondrieantistoff samt antistoffer mot glatt muskulatur, som alle var negative Ultralyd av lever avdekket biliære hamartomer, noe som ble tolket som et tilfeldig funn.

Pasienten ble utskrevet etter fem dager på sykehus. Utslettet var da gått nesten helt tilbake, hun var afebril og i klart bedre allmenntilstand. Blodkulturene hadde ikke vist oppvekst av bakterier og dyrking fra hals viste normalflora. Det ble besluttet at hun skulle fortsette på fenoksymetylpenicillin til total behandlingstid på ti dager. Ved utskrivning hadde hun følgende blodprøvefunn: CRP 9, ASAT 117 U/l, ALAT 291 U/l, gammaGT $174 \mathrm{U} / \mathrm{l}$ og albumin $35 \mathrm{~g} / \mathrm{l}$.

To dager etter at pasienten ble utskrevet, kom det foreløpig svar fra Folkehelseinstituttet om at serologisk prøve var positiv for parvovirus B19-IgM, men negativ for IgG. Dette viruset gir erythema infectiosum, også kalt den femte barnesykdom, en sykdom som kan gi generalisert utslett. Svaret ble i første omgang vurdert som uspesifikt, da man skulle kunne forvente IgG-stigning siden prøven var tatt over ti dager etter symptomdebut. Det ble avtalt poliklinisk time for blodprøver fire uker etter utskrivning. Ved serokonversjon skulle man da kunne forvente en økning av IgG for parvovirus B19.

Fem dager etter utskrivning kom endelig svar fra Folkehelseinstituttet. Pasienten var positiv for antihumant parvovirus B19-IgM lanalysert ved enzymbasert immunologisk analyse, EIAI, men negativ for humant parvovirus B19-DNA lanalysert ved polymerasekjedereaksjon, PCR). Konklusjonen var at den positive reaksjonen for parvovirus B19-IgM var en sannsynlig uspesifikk IgMreaksjon mot parvovirus. Pasienten var imidlertid positiv for både IgM (ved EIA) og IgG lved testene "Microimmune measles IgG capture ElA» og «Enzygnost»). Det ble på denne basis konkludert med at aktuell infeksjon med meslinger var sannsynlig. Det ble tatt kontrollserologi av parvovirus B19IgM og parvovirus B19-IgG fire uker etter utskrivning, og begge prøvene var negative. 
Vår pasient hadde kliniske symptomer forenlig med meslinger og positiv IgM. Hun fikk på den basis diagnosen meslinger. $\mathrm{Pa}$ sienten ble satt opp til poliklinisk time seks uker etter utskrivning for klinisk undersøkelse og kontroll av leververdier.

Ved poliklinisk kontroll hadde pasientens leverprøver fullstendig normalisert seg: ALAT 21, gamma-GT 49, INR 1,2. Hun var klinisk sett helt upåfallende, og det ble konkludert med at hun hadde gjennomgått en meslinginfeksjon.

\section{Diskusjon}

Meslingvirus er et enkelttrådet RNA-virus i paramyxoviridaefamilien. Mennesket er eneste bærer. Virusets inngangsporter er primært respirasjonsorganer og conjunctiva ved kontaktsmitte eller inhalasjon av små dråper i aerosol. Viruset er svært smittsomt. Hvis viruset er oppløst i aerosol, kan det smitte en person i samme rom i opptil en time etter at smittekilden har forlatt rommet (1). Risiko for smitte er størst de tre siste dagene før utslettet opptrer. Av ikke-immune personer i samme husholdning som en som er smittet, vil 75-90 \% utvikle sykdommen (2). Etter en inkubasjonstid på 8-12 dager starter prodromalfasen med feber, hoste, konjunktivitt og katarralia. Koplikske flekker, som er saltkornliknende flekker på innsiden av munnslimhinnen, opptrer gjerne 1-4 dager før utslettet debuterer og oppfattes som et patognomonisk tegn på meslinger (3). Allmennsymptomene tiltar i 2-4 dager frem til utslettet opptrer, og kulminerer gjerne omkring utslettets første dag (4). Utslettet starter i ansiktet, tiltar gjennom 2-3 dager og brer seg sentrifugalt til kroppen og ekstremitetene. Det vil typisk konfluere i ansiktet og på truncus. Utslettet forsvinner i løpet av 3-7 dager i samme rekkefølge som det kom, og følges gjerne av lett flassing (4). Meslinger er en sjelden sykdom i Norge i dag (fig 1) (5).

WHOs definisjon av et sikkert tilfelle av meslinger krever kliniske symptomer og tegn som passer med diagnosen samt laboratoriebekreftelse $\mathrm{i}$ form av positiv IgM mot meslinger, viruspåvisning gjennom isolering eller polymerasekjedereaksjonstest eller signifikant stigning i mesling-IgG i serumpar (6). IgM blir positiv i løpet av de første fem dagene etter at utslettet opptrer, når høyeste nivå etter 7-10 dager og kan sjelden påvises lenger enn 6-8 uker. I land der insidensen av meslinger er lavere enn 1 per million, anbefales det at positiv IgM suppleres med tilleggsundersøkelser for sikker diagnostikk (6). I dette tilfellet ble det også påvist positiv IgG mot meslinger, om enn ikke titerstigning i serumpar.

Meslinger er uten tvil den mest alvorlige av de «barnesykdommene» vi i dag vaksinerer mot. Dødeligheten er høyest hos spedbarn (første leveår), men er også høyere hos personer over 20 år. Sykdommen fører til en

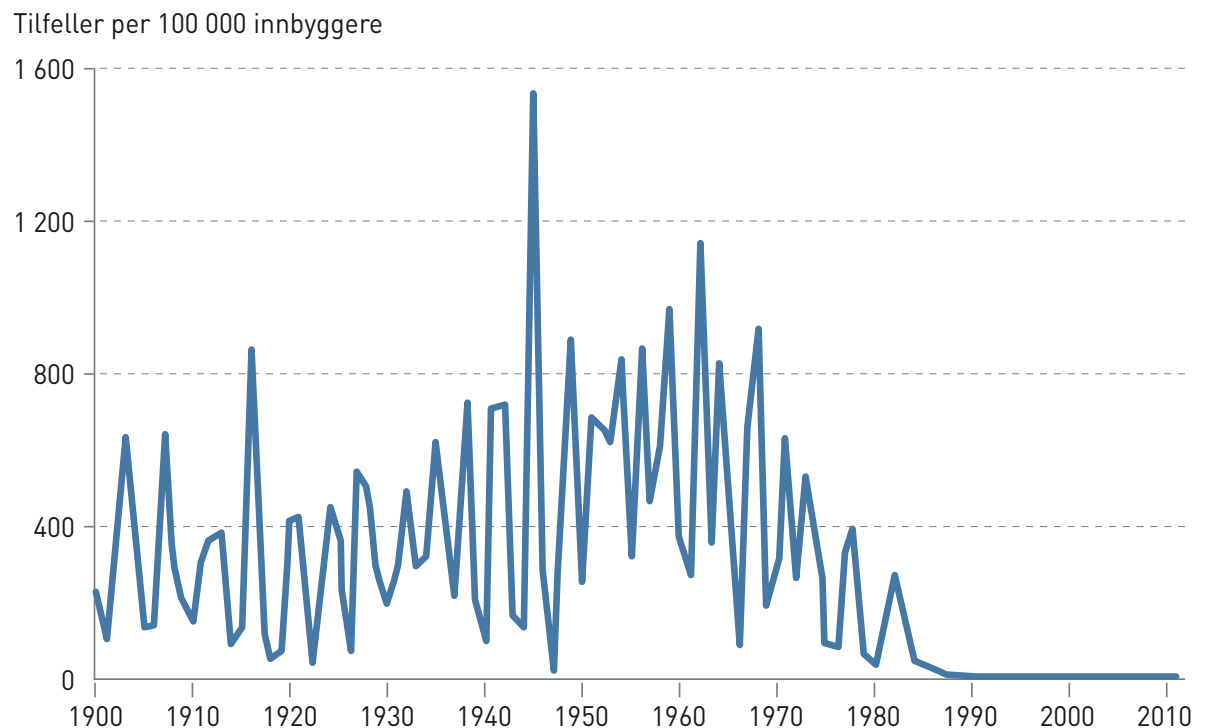

Figur 1 Forekomst av meslinger i Norge de siste hundre år. Tall fra Smittevernboka, Folkehelseinstituttet, gjengitt med tillatelse

forbigående immunsvikt med fall i CD4lymfocytter $(4,7)$, hvilket sannsynligvis er årsaken til at de vanligste komplikasjonene til meslinger er bakterielle superinfeksjoner. Den hyppigste komplikasjonen er otitt, men andre vanlige infeksjoner er laryngotrakeobronkitt og pneumoni. Pneumoni er også den hyppigste årsaken til dødsfall etter meslinger. Hos pasienter med nedsatt immunforsvar er diffus viral pneumoni forårsaket av meslingvirus en fryktet og dødelig komplikasjon (4).

Komplikasjonene varierer i noen grad med pasientens alder. Hepatitt, som hos vår pasient, forekommer særlig hos unge voksne. Andre gastrointestinale komplikasjoner, som diaré og dehydrering, kan ramme alle aldersgrupper (4).

Den mest fryktede komplikasjonen hos immunkompetente pasienter er postinfeksiøs encefalitt, som ses hos $1-3$ av 1000 pasienter (8), hyppigere hos ungdom og voksne enn hos skolebarn. Sannsynligvis skyldes meslingencefalitt en abnorm immunrespons (9). 25 \% av dem som får encefalitt dør, og omkring $1 / 3$ av de overlevende får varige skader (4). Subakutt, skleroserende panencefalitt (SSPE) er en sjelden komplikasjon (1 av 8-9 millioner) som skyldes at meslingvirus persisterer i sentralnervesystemet og fører til en langsomt progredierende infeksjon og demyelinisering. Risikoen for subakutt, skleroserende panencefalitt er høyest etter meslinger i første leveår, men gir de første symptomene først etter flere år, gjerne i form av avtakende skoleprestasjoner. Sykdommen progredierer til en nærmest vegetativ tilstand (4).

Vaksine mot meslinger består av levende, svekkede meslingvirus dyrket på kyllingfosterfibroblaster. Vaksinen ble tatt inn i det norske barnevaksinasjonsprogrammet i 1969. Den ble gitt ved 12-15 måneders alder. De første årene lå vaksinasjonsdekningen på omkring $70 \%$, men økte mot slutten av 1970-årene. I 1983 ble meslingvaksinen erstattet av en kombinasjonsvaksine mot meslinger, kusma og røde hunder, MMR-vaksinen (Measles, mumps, rubella). Samtidig ble det innført en tilleggsdose ved 12 års alder. Etter at MMR-vaksinen ble innført, har vaksinasjonsdekningen i Norge ligget godt over $90 \%$, unntatt i noen få år på begynnelsen av 2000-tallet. På denne tiden skapte debatten om mulig sammenheng mellom MMR-vaksine og autisme betydelig vaksineskepsis i en rekke land, inkludert Norge. Hypotesen om sammenheng ble fremmet i en artikkel av Andrew Wakefield i tidsskriftet The Lancet (10). En rekke senere undersøkelser taler sterkt imot en slik sammenheng. Senere har det også kommet frem at Wakefield mottok betydelige honorarer fra en gruppe som arbeidet for at barn med autisme skulle få erstatning fra vaksineprodusenten. I 2011 har det også kommet frem at han forfalsket sine data (11) og The Lancet har trukket den opprinnelige artikkelen tilbake.

Immunstatusundersøkelser har vist at over $97 \%$ av nordmenn født før meslingvaksinasjonen ble innført i 1969 har hatt meslinger (12). Hyppigheten av meslinger avtok raskt etter at vaksinasjonsprogrammet kom i gang. Det er grunn til å tro at immuniteten er dårligere hos personer født $\mathrm{i}$ siste halvdel av 1960-årene, siden de ikke har fått tilbud om vaksine og vokste opp i en periode der sannsynligheten for å bli smittet avtok. Vår pasient tilhører denne gruppen. Personer født i 1971 eller senere har fått tilbud om MMR-vaksine i skolealder og er sannsynligvis bedre beskyttet.

Smittekilden for vår pasient er ukjent. En mulighet er at hun er blitt smittet av en av flyktningene hun kom i kontakt med på jobben. Klinisk diagnostisering av meslinger er 
usikker i land der sykdommen er sjelden (13). Mange norske leger har knapt sett sykdommen, tenker neppe på den og kanskje særlig ikke hos et barn der hudfargen kan gjøre utslettet mindre typisk for våre øyne. Sykehistorien til vår pasient reiser derfor spørsmålet om vi har ikke-erkjente tilfeller av meslinger blant pasienter fra områder der sykdommen er vanligere enn i vår del av verden. Slike pasienter vil i så fall til utgjøre en klar risiko for reintroduksjon av meslinger i Norge.

WHO hadde som mål å utrydde meslinger i Europa-regionen innen 2010. Større og mindre utbrudd i en rekke europeiske land gjennom de siste ti årene gjorde dette umulig (14), og målet er nå utrydding innen 2015 (15). Også dette vil kreve betydelig økt innsats, ikke minst i forhold til svake grupper der vaksinasjonsdekningen er særlig lav. Det viste ikke minst det store utbruddet blant romfolket i Bulgaria i 2010 (16).

I Norge har det bare vært små og spredte utbrudd av meslinger gjennom de siste 20 årene. Et par utbrudd i 1990-årene var knyttet til Steinerskoler (17), mens noen tilfeller i det antroposofiske miljøet på Nøtterøy i 2008 hadde utspring $i$ et større utbrudd i tilsvarende miljøer i Østerrike og Tyskland (18). Et utbrudd blant «engelske reisende» i Norge i 2007, med 19 tilfeller, hadde sammenheng med et stort utbrudd i den samme gruppen i Storbritannia (19). Utbruddet førte ikke til noen tilfeller i den vanlige norske befolkningen, noe som tyder på at den generelle immuniteten i befolkningen er god. I løpet av vinteren og våren 2011 har import av meslingvirus ført til smitte flere ganger i Norge. Det største utbruddet besto av 23 tilfeller og har utgangspunkt $\mathrm{i}$ et innvandrermiljø i Oslo (20). I dette utbruddet har flere av pasientene sannsynligvis blitt smittet på venteværelset hos lege/legevakt, en smittemåte som er kjent også fra andre land $(21,1)$. Utbruddet i Oslo er i skrivende stund (april 2011) fremdeles pågående. Det er derfor en klar advarsel om at introduksjon av meslinger lett kan skje også i vårt land. Bare vedvarende og høy oppslutning om vaksinasjonen kan hindre det.
Pasienten har gitt samtykke til at artikkelen blir publisert.

\section{Sveinung Larsen}

er lege i spesialisering ved Barneavdelingen,

Sykehuset Innlandet, Lillehammer.

Forfatter har fylt ut ICMJE-skjemaet og oppgir ingen interessekonflikter.

\section{Hanne Nøkleby}

er spesialist i barnesykdommer og divisjonsdirekt $\varnothing r$, Divisjon for smittevern, Nasjonalt folkehelseinstitutt.

Forfatter har fylt ut ICMJE-skjemaet og oppgir ingen interessekonflikter.

\section{Dag Amundsen}

er spesialist i lungesykdommer og i allmennmedisin. Han er overlege ved Indremedisinsk avdeling, Sykehuset Innlandet, Lillehammer. Forfatter har fylt ut ICMJE-skjemaet og oppgir ingen interessekonflikter.

\section{Litteratur}

1. Remington PL, Hall WN, Davis IH et al. Airborne transmission of measles in a physician's office. JAMA 1985; 253: 1574-7.

2. Simpson RE. Infectiousness of communicable diseases in the household (measles, chickenpox, and mumps). Lancet 1952: 2: 549-54.

3. Suringa DWR, Bank LJ, Ackerman AB. Role of measles virus in skin lesions and Koplik's spots. N Engl J Med 1970; 283: 1139-42.

4. Perry RT, Halsey NA. The clinical significance of measles: a review. J Infect Dis 2004; 189 (suppl 1): S4-16

5. Folkehelseinstituttet. Smittevernboka. www.fhi.no/ eway/default.aspx?pid=233\&trg=MainLeft_6039\& MainArea $5661=6039: 0: 15,5078: 1: 0: 0: 0: 0 \&$ MainLeft_6039 $=6041: 82822: 1: 6043: 80: 0: 0$ (30.6.2011).

6. WHO. Surveillance Guidelines for Measles, Rubella and Congenital Rubella Syndrome in the WHO European Region. København: World Health Organization, 2009

7. Griffin DE, Bellini WJ. Measles virus. I: Fields BN, Knipe DM, Howley PM, red. Fields' virology. Philadelphia, PA: Lippincott-Raven, 1996.1267.

8. Gibbons JL, Miller HG, Stanton JB. Para-infectious encephalomyelitis and related syndromes; a critical review of the neurological complications of certain specific fevers. Q J Med 1956; 25: 427-505.
9. Johnson RT, Griffin DE, Hirsch RL et al. Measles encephalomyelitis-clinical and immunologic studies. N Engl J Med 1984; 310: 137-41.

10. Wakefield AJ, Murch SH, Anthony A et al. Ileallymphoid-nodular hyperplasia, non-specific colitis, and pervasive developmental disorder in children Lancet 1998; 351: 637-41. Tilbaketrekking: Lance 2010; $375: 445$

11. Deer B. Secrets of the MMR scare. How the vaccine crisis was meant to make money. BMJ 2011: 342: $c 5258$.

12. Flugsrud LB, R?d TO, Aasen $\mathrm{S}$ et al. Measles antibodies and herd immunity in 20- and 40-year-old Norwegians. Scand J Infect Dis 1997: 29: 137-40.

13. Hutchins SS, Papania MJ, Amler R et al. Evaluation of the measles clinical case definition. J Infect Dis 2004; 189 (suppl 1): S153-9

14. Muscat M, Bang H, Wohlfahrt J et al. Measles in Europe: an epidemiological assessment Lance 2009; 373: 383-9.

15. WHO. Renewed commitment to measles and rubella elimination and prevention of congenital rubella syndrome in the WHO European Region by 2015. København: World Health Organization, 2010

16. EUVAC.NET. Measles outbreak in Bulgaria: update as of week 29, 2010. www.euvac.net/graphics/ euvac/outbreak/bulgaria29.html (30.6.2011).

17. Hagen KH. Meslingeepidemi vinteren 1996/97 i Nesodden. MSIS-rapport nr. 23/1997. Oslo: Folkehelseinstituttet, 1997.

18. Schmid D. Holzman H, Abele $\mathrm{S}$ et al. An ongoing multi-state outbreak of measles linked to nonimmune anthroposophic communities in Austria, Germany, and Norway, March-April 2008. Euro Surveill 2008; 13: pii=18838. www.eurosurveillance. org/ViewArticle.aspx?Articleld=18838 (30.6.2011).

19. Løvoll $\varnothing$. Vonen L, Nordbø SA et al. Outbreak of measles among Irish Travellers in Norway: an update. Euro Surveill 2007; 12: pii=3217. www.eurosurveillance.org/ViewArticle.aspx? Articleld $=3217$ (30.6.2011)

20. Vainio K, Rønning K, Steen TW et al. Ongoing outbreak of measles in Oslo, Norway, January-February 2011. Euro Surveill 2011; 16: pii=19804. www.eurosurveillance.org/ViewArticle.aspx? Articleld $=19804$ (30.6.2011)

21. Follin $P$, Dotevall $L$, Jertborn $M$ et al. Effective control measures limited measles outbreak after extensive nosocomial exposures in January February 2008 in Gothenburg. Sweden. Euro Surveill 2008; 13: pii=18937. www.eurosurveillance.org/ ViewArticle.aspx?Articleld=18937 (30.6.2011).

Mottatt 21.10. 2010, første revisjon innsendt 4.1 2011, godkjent 30.6. 2011. Medisinsk redaktør Lars Frich. 